Khazanah: Jurnal Studi Islam dan Humaniora

ISSN: 0215-837X (p); 2460-7606 (e), Vol. 19 (1), 2021, pp. 21-38

DOI: $10.18592 /$ khazanah.v19i1.4938

Submit: 24/07/2021 Review: 26/07/2021 Publish: 30/07/2021

\title{
NUANSA FIQIH DALAM PEMIKIRAN TEOLOGI SYEKH MUHAMMAD ARSYAD AL-BANJARI PADA RISALAH TULFAT AL-RÂGHIBIN
}

\author{
Muhammad Iqbal \\ Universitas Islam Negeri Antasari Banjarmasin \\ iqbal.ego@gmail.com
}

\begin{abstract}
This article examines the theological thoughts of Sheikh Mubammad Arsyad al-Banjari in Tubfat al-Râghibin. Although it is a treatise on theology that actually deals with theoretical aspects (nazharî), it discusses extensively practical aspects ('amalî). With Arsyad al-Banjari's background as an expert in Islamic law, these practical aspects are described using some notions developed in Islamic jurisprudence (fiqh). As a result, the nuances of fiqh are so evident in this treatise. This can be observed from the use of deontik modalities and argumentation models of figh to explain issues related to theology. Moreover, this treatise follows the deep structure of the so-called al-hukm al-wadh'î in Islamic law to describe the concept of faith.
\end{abstract}

Keywords: Arsyad al-Banjari; Tubfat al-Râghibin; theology; Shariah, fiqh

Abstrak: Artikel ini menganalisa pemikiran teologi Syekh Muhammad Arsyad al-Banjari dalam Tuhfat al-Râghibîn. Walaupun ini risalah tentang akidah yang sebenarnya membahas aspek-aspek teoritis (nazharî), tapi ia banyak mendiskusikan aspek-aspek praktis ('amalî). Dengan latar belakang Arsyad alBanjari sebagai seorang abli fiqih, maka aspek-aspek praktis ini diuraikan dengan menuggunakan beberapa ide yang dikembangkan dalam yurisprudensi Islam (fiqib). Alhasil, nuansa fiqih sangat kentara dalam risalab ini. Ini terlihat dari penggunaan modalitas deontik dan model argumentasi fiqih untuk menguraikan persoalan-persoalan yang terkait dengan aqidah. Lebih dari itu, risalah ini mengikuti struktur dalam (deep structure) bukum wadh'î dalam fiqih untuk menjelaskan konsep keimanan.

Kata kunci: Arsyad al-Banjari; Tuhfat al-Râghibîn; aqidah; Syariah, fiqih

\section{Pendahuluan}

Tidak mungkin dipungkiri bahwa Syekh Muhammad Arsyad al-Banjari (17101812) merupakan tokoh penting dalam sejarah penyebaran Islam di masyarakat Banjar. Salah satu kontribusinya yang paling signifikan adalah membangun sebuah pusat pendidikan Islam, semacam pesantren saat ini, di suatu kampung yang dikenal sebagai "kampung dalam pagar", sebuah daerah yang terletak tidak jauh dari Martapura, ibu kota Kabupaten Banjar. Pusat pendidikan ini merupakan pesantren pertama di Kalimantan dan telah mencetak banyak ulama terkemuka yang menyebarkan dan mengajarkan Islam tidak hanya di tanah Banjar, tapi juga di beberapa wilayah di Asia Tenggara. Dengan kata lain, Arsyad al-Banjari tidak hanya berkontribusi bagi perkembangan Islam di tanah kelahirannya, Kalimantan selatan, tapi juga di Asia Tenggara secara lebih luas. Ini juga terbukti dari fakta bahwa karyanya tidak hanya dibaca oleh masyarakat Banjar atau, secara lebih umum, Indonesia, tapi juga dibaca 
oleh masyarakat Muslim Asia Tenggara lainnya seperti Malaysia, Thailand, Brunei dan Kamboja. ${ }^{1}$

Arsyad al-Banjari dikenal sebagai seorang ahli hukum (fâqib), terutama melalui karya utamanya Sabîl al-Mubtadîn. Kitab ini, sebagaimana diungkapkan Steenbrink, merupakan kitab fiqih dalam bahasa Melayu yang paling lengkap dan sistematis. Tidak ada kitab fiqih berbahasa Melayu yang tersebar luas seperti karya Arsyad al-Banjari ini. ${ }^{2}$ Karya yang disusun atas permintaan Sulthân Tamjîd Allâh ini bahkan telah dicetak di berbagai belahan dunia. ${ }^{3}$

Keahlian Arsyad al-Banjari dalam ilmu fiqih inilah tampaknya yang berperan penting dalam usulan pendirian Mahkamah Syari'ah di Kesultanan Banjar pada saat itu. Mahkamah Syari'ah dipimpin oleh seorang Muftî and Qâdhî. Yang pertama bertugas untuk mengeluarkan fatwa, sedang yang kedua bertugas membuat keputusan untuk kasus-kasus tertentu berdasarkan hukum Islam. Muhammad As'ad, cucu Arsyad alBanjari, diangkat sebagai Muftî pertama dan Abu Su'ud, putranya, diangkat sebagai Qâdhî pertama. ${ }^{4}$ Dengan berdirinya Mahkamah ini, hukum Islam, khususnya menurut mazhab Syafi'i yang dianut olehnya, menjadi rujukan dalam setiap perkara hukum, baik perdata maupun pidana.

Di sisi lain, pendirian Mahkamah Syari'ah menunjukkan kecenderungan Arsyad al-Banjari kepada aspek praktis ('amali). Kalau kita melihat model keislaman urang Banjar awal yang sebenarnya cenderung kepada mistik, yakni yang lebih menekankan kepada aspek esoteris (tasawuf), ${ }^{5}$ maka apa yang dilakukan oleh Arsyad al-Banjari ini dapat dipahami sebagai upaya untuk merubah model keislaman masyarakat Banjar pada

${ }^{1}$ Muhammad 'Uthman El-Muhammady, "Aqidah Ahli Sunnah Wal-Jamaah menurut Syeikh Muhammad Arsyad al-Banjari”. Dalam Abdul Rahman Abdullah, Biografi Agung Sheikh Arshad al-Banjari (Shah Alam, Selangor: Karya Bestari, 2016), 212-261; Aswadie Syukur, "Pemikiran Syeikh Muhammad Arsyad al-Banjari dalam Bidang Fiqh (1); Kitab Sabil al-Muhtadin”. Dalam Abdul Rahman Abdullah, Biografi Agung Sheikh Arshad al-Banjari (Shah Alam, Selangor: Karya Bestari, 2016), 290-302. 1984), 91

${ }^{2}$ K. A. Steenbrink, Beberapa Aspek tentang Islam di Indonesia Abad ke19 (Jakarta: Bulan Bintang,

${ }^{3}$ Naskah Sabîl al-Mubtadîn pertama kali disunting oleh Ahmad ibn Muhammad Zain al-Fathani dan diterbitkan hampir bersamaan di Mekah dan Istanbul sekitar tahun 1882. Lihat Aswadie Syukur, "Pemikiran Syeikh Muhammad Arsyad al-Banjari ....". Naskah kitab ini juga disunting oleh Muhammad Ilyas al-Azhari dan diterbitkan di Kairo pada tahun 1307H/ 1889. Lihat Fathullah Munadi, Teks dan Naskah Sabîl al-Mubtadîn: Kajian Filologi atas Karya Syekh Mubammad Arsyad. Retrieved from https://www.academia.edu/41958304/TEKS_DAN_NASKAH_SAB\%C4\%AAL_AL_MUHTAD \% C4\%AAN_KAJIAN_FILOLOGI_ATAS_KARYA_SYEKH_MUHAMMAD_ARSYAD. Selain itu, naskah ini tentu saja dicetak di beberapa negara Asia tenggara seperti Indonesia dan Malaysia. Di Indonesia, Sabîl al-Mubtadîn telah diterjemahkan oleh Aswadie Syukur dan telah diterbitkan oleh Bina Ilmu Surabaya sejak tahun 1985. Di Malaysia, kitab ini diterbitkan oleh Telaga Biru sejak 2010 setelah sebelumnya naskahnya ditransliterasi oleh Mohamad Haidzir bin Hussin bin Ibrahim dan diedit oleh Fuad Ismail. Selain itu juga ada Kitab Sabîll al-Mubtadîn yang diterbitkan oleh Jahabersa, Johor Baru sejak tahun 2013.

1968).

${ }^{4}$ Yusuf Halidi, Ulama Besar Kalimantan Selatan Syekh Arsyad al-Banjari (Surabaya: al-Ikhsan,

5Lihat Irfan Noor, "Visi Spiritual Masyarakat Banjar", Al-Banjari, Vol. 12 No. 2, 2013, 160. 


\section{Nuansa Fiqih dalam Pemikiran Teologi \\ Syekh Muhammad Arsyad Al-banjari pada Risalah Tuhfat Al-râghibîn}

saat itu. ${ }^{6}$ Dalam konteks inilah tampaknya Zurkani Jahja menyebut Arsyad al-Banjari sebagai tokoh yang telah menciptakan zaman baru dalam sejarah Islam Kalimantan Selatan; dan bentuk keislaman masyarakat Banjar saat ini merupakan model yang diwarisi dari ajaran tokoh yang sering disebut masyarakat Banjar sebagai Datu Kalampayan ini. ${ }^{7}$

Upaya untuk merubah model keberagamaan masyarakat Banjar ini sebenarnya tergambar dalam salah satu karyanya, Tubfat al-Râghibîn, yang ditulis dua tahun setelah kembali dari studi selama 35 tahun di Mekah dan Madinah. Tepatnya, risalah ini disusun pada tahun 1188H/1774. Dalam karya ini Arsyad al-Banjari mengkritik berbagai model keislaman yang dianggap menyimpang, salah satunya adalah model keislaman mistik yang saat itu berkembang di masyarakat Banjar. Selain itu, Arsyad alBanjari juga mengkritik ritual-ritual lokal tertentu yang dipraktikkan masyarakat Banjar karena dianggap menyimpang dari ajaran Islam.

Tuhfat al-Râghibin adalah salah satu karya Arsyad al-Banjari dalam Ilmu Tauhid selain kitab Ushûl al-Dîn dan Hidâyat al-Mustarsyidîn. ${ }^{8}$ Menariknya, meskipun ini adalah kitab aqidah yang berbicara tentang aspek teoritis (nazhari), namun dalam pembahasannya, sebagaimana diungkapakan M. Rusydi, karya ini banyak merujuk kepada ilmu fiqih, terutama dalam madzhab Syafi' $1 .{ }^{9}$ Oleh karenanya, perlu dikaji secara lebih spesifik bagaimana ide-ide yang dikembangkan dalam fiqih digunakan Arsyad alBanjari untuk menjelaskan persoalan-persoalan teologis dalam risalah Tuhfat alRâghibîn.

\section{Metode}

Penelitian ini adalah penelitian pustaka (library research) ${ }^{10}$ dengan pendekatan kualitatif (qualitative approach) ${ }^{11}$ yang fokus kepada nuansa fiqih pada pemikiran teologi Syekh Arsyad al-Banjari. Dalam hal ini, data-data yang relevan dengan ide-ide tersebut ditelusuri secara terbatas dalam risalah Tuhfat al-Râghibîn. Data-data yang relevan

\footnotetext{
${ }^{6}$ Mengenai perkembangan model keislaman urang Banjar dapat dilihat di Muhammad Iqbal Noor, "Nalar Keislaman Urang Banjar”, Al-Banjari, Vol.10. No.2, 2011, 185-204.

7Zurkani Jahja, "Pemikiran Syeikh Muhammad Arsyad al-Banjari dalam Bidang Tauhid". Dalam Abdul Rahman Abdullah, Biografi Agung Sheikh Arshad al-Banjari. Dalam Abdul Rahman Abdullah, Biografi Agung Sheikh Arshad al-Banjari (Shah Alam, Selangor: Karya Bestari, 2016), 262-289.

${ }^{8}$ Dua kitab ini membicarakan tentang sifat dua puluh. Kitab yang terakhir, Hidâyat alMustarsyidîn, diketahui dan ditemukan baru-baru ini. Sebelumnya, kitab ini belum pernah disebutkan baik dalam biografi-biografinya maupun dalam studi-studi tentang figur maupun karya-karyanya. Kitab ini ditulis pada tahun 1762 ketika Arsyad al-Banjari masih bermukim di Mekah. Lihat Mujiburrahman, M. Rusydi, Muhammad Iqbal \& Adi Hatim, Pemikiran Teologi Syekh Mubammad Arsyad al-Banjari dalam Kitab Hidâyat al-Mustarsyidîn, Proposal Penelitian, UIN Antasari Banjarmasin, Banjarmasin, 2021.

${ }^{9}$ M. Rusydi, "Ideologi dan Epistemologi Kitab Tuhfah ar-Râghibîn Karya Muhammad Arshad al-Banjari, Islamica: Jurnal Studi Keislaman, Vol. 8, No.2, 2014, 475-502; M. Rusydi, "Analisis atas Tubfah ar-Rághibin Karya Muhammad Arsyad al-Banjari” Al-Banjari, Vol. 9 No.1, 2010, 35-58.

${ }^{10}$ Lihat Kartini Kartono, Pengantar Metodologi Riset Sosial (Bandung: Mandar Maju, 1996), 33.

${ }^{11}$ Tentang pendekatan kualitatif dalam penelitian, silahkan lihat John W. Creswell, Research Design: Qualitative, Quantitative, and Mixed Methods Approaches, Third Edition (Los Angeles: Sage, 2009), 14-15.
} 
tersebut kemudian diklasifikasi secara sistematis untuk kemudian dianalisa secara filosofis dengan metode interpretasi dan komparasi. ${ }^{12}$

Untuk menguraikan nuansa fiqih dalam pemikiran teologi Arsyad al-Banjari sebagaimana yang dimaksud di atas, pertama-tama akan dilihat bagaimana penekanan terhadap aspek praktis ('amali) dengan mengkaji persoalan-persoalan yang didiskusikan dan juga konsep keimanan yang diuraikan dalam risalah Tuhfat al-Râghibîn. Kemudian, kita juga akan melihat bagaimana ide-ide yang dikembangkan dalam fiqih digunakan oleh Arsyad al-Banjari untuk membahas persoalan-persoalan teologis. Untuk itu, kita akan memperlihatkan tiga aspek fiqih dalam Tuhfat al-Râghibîn: modalitas deontik, model penalaran dan argumentasi, dan struktur dalam (deep structure) hukum dalam fiqih. Namun sebelum membahas semua itu, perlu diuraikan terlebih dahulu latar belakang intelektual Arsyad al-Banjari untuk melihat bagaimana secara historis kecenderungan pada fiqih ini muncul.

\section{Pembahasan}

\section{Latar Belakang Intelektual Syekh Muhammad Arsyad al-Banjari}

Arsyad al-Banjari lahir pada Shafar 1122H/Maret 1710 di Lok Gabang, Martapura, Kalimantan Selatan. Beliau wafat pada bulan Syawal 1227H/Oktober 1812 di Desa Dalam pagar, dan dimakamkan di Kalampayan. Pendidikan dasar agamanya sepertinya diperoleh dari orang tuanya dan guru lokal di desanya sendiri, karena tidak diketahui bahwa ada sekolah Islam di Banjar selama masa kecilnya. Saat berusia tujuh tahun, Arsyad al-Banjari terkenal dengan kecerdasannya dan lukisan-lukisannya yang mengesankan. Ini menarik perhatian Sulthân Tahlîl Allâh (1112-58/1700-45) yang kemudian membawanya tinggal di Istana Kesultanan untuk mendapatkan pendidikan lebih lanjut, khususnya dalam ilmu agama. ${ }^{13}$

Saat berusia sekitar 30 tahun, Arsyad al-Banjari pergi ke Mekah untuk melanjutkan studi dengan biaya dari Kesultanan. Di Mekah, sebagaimana disebutkan oleh Azyumardi Azra, Arsyad al-Banjari dan rekan-rekannya dari Nusantara seperti 'Abd al-Shamad al-Palimbani dan Dâwûd al-Fathânî belajar dengan 'Athâ' Allâh alMashrî al-Azharî al-Makkî, ${ }^{14}$ ulama Syafi'i yang dikenal sebagai ahli sastra dan logika. Al-Mashrî menulis beberapa karya sastra dan logika, di antaranya adalah Nibâyat al-

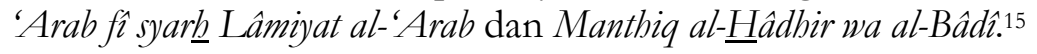

\footnotetext{
${ }^{12}$ Tentang metode interpretasi dan komparasi dalam penelitian filsafat, lihat Anton Bakker dan Achmad Charris Zubair, Metodologi Penelitian Filsafat (Yogyakarta: Penerbit Kanisius, 1990), 41-43, 50-51.

${ }^{13}$ Yusuf Halidi, Ulama Besar Kalimantan Selatan Syekh Arsyad al-Banjari.

${ }^{14}$ Azyumardi Azra, The Origins of Islamic reformism in Southeast Asia: networks of Malay-Indonesian and Middle Eastern 'Ulamâ' in the seventeenth and eighteenth centuries. (Crows Nest; Honolulu: Allen \& Unwin; University of Hawai'i Press, 2004).

${ }^{15}$ Lihat 'Umar Riḍ̂ Kahâla, Mu'jam al-Mu'allifiñ ; Tarâjum Mu'alifî al-Kutub al-'Arabiyya. Vol.2. (Beirut: Mu'assasat al-Risâlah, 1993), 379; 'Abd al-Fattâh 'Âyish and Qaishar, Mu'jam al-Adibbâ' min 'Ashr al-Jâhilî hattâ sana 2002. Vol. 4 (Beirut: Dâr al-Kutub al-'Ilmiyyah, 2003), 222; Khair al-Dîn alZarkalî, al-A'lâm. vol.4 (Beirut: Dâr al-'Ilm li al-Malâyîn, 2002), 236.
} 


\section{Nuansa Fiqih dalam Pemikiran Teologi \\ Syekh Muhammad Arsyad Al-banjari pada Risalah Tuhfat Al-râghibîn}

Arsyad al-Banjari juga berkesempatan untuk belajar dari 'Abd al-Mun'îm alDamanhûrî (1101H/1690-1192H/1778), seorang cendekiawan Mesir yang pernah menjadi rektor pada periode 1768-1778.16 Al-Damanhûrî dikenal mahir dalam ilmu transmisi ('ilm al-naqli) dan ilmu rasional ('ilm al-'aqlí) termasuk logika, retorika, teologi rasional, yurisprudensi, bacaan $\mathrm{Al}$-Qur'an, kedokteran, anatomi dan aritmatika. Dalam hal fiqih, al-Damanhûrî terkenal karena pengetahuannya tentang empat mazhab hukum Islam Sunni. ${ }^{17}$

Masih ingin memperluas dan memperdalam ilmunya, bersama rekan-rekannya dari Nusantara, Arsyad al-Banjari melanjutkan studinya di Madinah. Di kota suci ini, beliau berguru kepada Muhammad ibn 'Abd al-Karîm al-Sammânî al-Madanî, sahabat al-Mashrî. Al-Sammânî lahir di Madinah sekitar tahun 1130H/1718 dan meninggal di

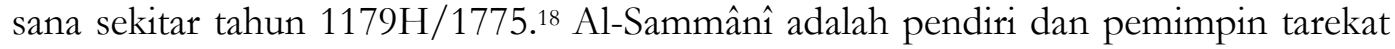
Sammâniyyah yang berafiliasi dengan tarekat Sufi Khalwatiyyah, al-Qâdiriyyah dan Syâdziliyyah.

Selain belajar tasawuf, di Madinah Arsyad al-Banjari juga masih terus mendalami fiqih dan berguru kepada Sulaimân al-Kurdî (1715-1780), salah seorang rekan al-Sammânî. Al-Kurdî dikenal sebagai ulama besar yang menguasai ílm al-naql dan 'ilm al-'aql, bahkan ia disebut sebagai salah satu gunung ilmu (jabalun min jibâl al'ilmi). Al-Kurdî adalah salah satu ulama Syafi'i paling terkemuka pada masanya dan menjadi mufti di Madinah. ${ }^{19}$ Al-Kurdî menulis beberapa karya penting tentang fiqih. Sebagaimana dikemukakan oleh van Bruinessen, di Indonesia karyanya yang paling terkenal adalah al-Hawâsyî al-Madaniyyah yang masih dicetak ulang di Indonesia. AlHawâsyî al-Madaniyyah merupakan sebuah komentar ekstensif atas al-Muqaddimah alHadhramiyyah karya Bâ-Fadhl. ${ }^{20}$

Al-Kurdî adalah guru yang paling berpengaruh terhadap pemikiran Arsyad alBanjari. Diriwayatkan bahwa Arsyad al-Banjari sering berkonsultasi dengan gurunya ini mengenai beberapa persoalan yang terjadi di tanah kelahirannya. Salah satunya terkait dengan keputusan Sultan Banjar untuk mendenda orang-orang yang tidak melaksanakan shalat Jum'at. Arsyad al-Banjari juga meminta al-Kurdî untuk menjelaskan perbedaan antara zakat dan pajak. Tanggapan al-Kurdî dicatat oleh Arsyad al-Banjari dalam karyanya Fatâwâ Syekh Sulaimân al-Kurdî yang ditulis dalam bahasa Arab.

${ }^{16}$ Moshe Perlmann, "Shaykh al-Damanhûurî against the churches of Cairo (1739)". Actas IV Congresso de Estudos Arabes e Islamicos: Coimbra-Lisboa, 1 a 8 de 'setembro de 1968 (Leiden: Brill, 1971), 2732.

${ }^{17}$ Lihat 'Abd al-Rahman al-Jabartî., Târîkh 'Ajầib al-Âthâr fî́ al-Tarâjum wa al-Akhbâr, vol.1 (Beirut: Dâr al-Jîll, 1998), 2725; 'Umar Riḍâ Kahâla, Mu'jam al-Mu'allifinin; Tarâjum Mu'alifî al-Kutub al'Arabiyyah, vol. 1, 303; Khair al-Dîn al-Zarkalî̀, al-A'lâm., vol. 1, 163.

${ }^{18}$ Lihat 'Umar Ridâ Kahâla, Mu'jam al-Mu'allifiñ ; Tarâjum Mu'alifîn al-Kutub al-'Arabiyyah.

${ }^{19}$ Lihat Bassâm 'Abd al-Wahâb al-Jâbị̂, "Tarjamah Muhammad ibn Sulaymân al-Kurdị/al-

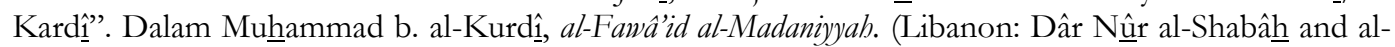
Jaffân wa al-Jâbị̂, 2011).

${ }^{20} \mathrm{M}$. van Bruinessen, "Kurdish 'Ulama and their Indonesian disciples" [revised version of: "The impact of Kurdish `ulama on Indonesian Islam"]”. Les annales de l'autre Islam, 5, 1998, 83-106 
Meskipun, dari karya-karya di bidang aqidah yang dihasilkannya dapat dipastikan bahwa Arsyad al-Banjari juga mempelajari ilmu aqidah secara mendalam. Tapi, jika melihat perjalanan intelektualnya di atas, terutama dari guru-guru yang paling berpengaruh, tampaknya Arsyad al-Banjari memang lebih memiliki kecenderungan pada ilmu fiqih dibanding ilmu-ilmu lainnya. Ini terbukti bahwa hingga di akhir-akhir masa studinya, Arsyad al-Banjari masih terus mendalami ilmu fiqih dan juga memiliki perhatian khusus tentang persoalan-persoalan fiqih di tanah Banjar hingga mengkonsultasikannya dengan gurunya, Sulaimân al-Kurdî.

\section{Tuhfat al-Râghibîn: Potret Dinamika Islamisasi Masyarakat Banjar}

Tuhfat al-Râghibin adalah salah satu karya terpenting dari Arsyad al-Banjari. Risalah ini diterbitkan beberapa kali di Istanbul, Mekah, Kairo, Singapura, dan Surabaya. Risalah ini dicetak pertama kali pada tahun 1887 di Istanbul oleh al-Mathba'a al- $\underline{H} a \hat{j}$ Muharram Afandî dan ditulis atas permintaan pihak kerajaan sebagaimana diungkapkan oleh pengarang di dalam kitab. Perlu diketahui ada perbedaan pendapat di kalangan sarjana keislaman di Asia Tenggara tentang siapa penulisnya karena memang nama penulis tidak disebutkan dalam beberapa naskah. ${ }^{21}$ Beberapa kalangan berpendapat bahwa risalah ini disusun oleh Abdul Samad al-Palimbani. Namun, argumen para peneliti yang dikompilasi oleh Mujiburrahman ${ }^{22}$ memberikan bukti kuat bahwa risalah ini ditulis oleh Arsyad al-Banjari, terutama mengenai diksi yang mirip dari doksologi beberapa karya Arsyad al-Banjari, penggunaan beberapa kata Banjar dan penyebutan beberapa tradisi Banjar. ${ }^{23}$ Selain itu, terbitan Mathba'ah al-A $\underline{\text { hmadiyyah }}$ Singapura dan al-Ihsan Surabaya pada tahun 1929 menyebutkan dengan jelas Arsyad al-Banjari sebagai penulis risalah tersebut.

Risalah Tubfat al-Râghibîn membicarakan tentang aqidah Ahl al-Sunnah wa alJamâ‘ah. Risalah ini terdiri dari tiga bab: pertama tentang hakikat iman dan Islam, kedua tentang hal-hal yang merusak iman, dan terakhir tentang taubat dan syarat-syaratnya. Sistematika penulisan risalah ini tampaknya menunjukkan bahwa yang menjadi fokus pembahasan bukanlah aspek teoritis (nazhari), tapi lebih kepada aspek praktis ('amali). Ini berbeda dengan umumnya pembahasan tentang aqidah yang lebih banyak menyinggung aspek teoritis (nazhari) seperti, misalnya, pembahasan tentang sifat dua puluh sebagaimana umumnya ajaran aqidah di Nusantara yang bersandar pada aliran Asy'ariyah.

${ }^{21}$ Norhaidi Hasan, "The Tuhfat al-Raghibin: The Work of Abdul Samad al-Palimbani or Muhammad Arsyad al-Banjari?” Bijdragen tot de Taal-, Land- en Volkenkunde (BKI) 163-1, 2007, 67-85.

${ }^{22}$ Termasuk didalamnya argumen yang diungkapkan dalam Yusran, Study Tentang Risalah Tubfatur Raghibin, Skripsi, (Fakultas Ushuluddin IAIN Antasari, Banjarmasin, 1988); Aswadie Syukur, Naskah Risalab Tuhfatur Raghibin (Laporan Penelitian IAIN Antasari Banjarmasin, 1990), dan; Norhaidi Hasan, "The Tuhfat al-Raghibin: The Work of Abdul Samad al-Palimbani or Muhammad Arsyad alBanjari?".

${ }^{23}$ Mujiburrahman. "Islamic Theological Texts and Contexts in Banjarese Society: An Overview of the Existing Studies". Southeast Asian Studies, 3/3, 2014, 611-641. 


\section{Nuansa Fiqih dalam Pemikiran Teologi \\ Syekh Muhammad Arsyad Al-banjari pada Risalah Tubfat Al-râghibîn}

Tampaknya ini memang sudah dirancang sedemikian rupa oleh Arsyad alBanjari sehingga kajian aqidah yang dipaparkan dalam risalah Tuhfat al-Râghibîn lebih bermakna bagi masyarakat Muslim Banjar yang saat itu, dalam pandangan beliau, sebagian dari mereka masih belum memiliki landasan aqidah yang kuat sehingga masih gamang dalam menyikapi praktik-praktik ritual lokal yang tidak sesuai dengan Syariah Islam, atau juga mudah terpapar aliran-aliran yang menyimpang. Hal ini menunjukkan bahwa risalah ini membahas tentang isu-isu yang aktual pada saat itu sehingga dapat dikatakan bahwa Tubfat al-Râgbibin adalah potret dinamika Islamisasi masyarakat Banjar.

Dinamika itu terlihat dalam perang wacana antara model keislaman yang dibawa oleh Arsyad al-Banjari dengan model keislaman yang sebelumnya berkembang di masyarakat Banjar, yakni keislaman yang lebih bersifat mistik (tasawuf). Ini terlihat dalam pembahasan tentang apa yang disebut sebagai aliran wujudiyah. Selain itu, dinamika Islamisasi masyarakat Banjar juga terlihat dalam perdebatan antara Arsyad alBanjari dan masyarakat lokal terkait dengan ritual-ritual yang sudah mereka lakukan secara turun temurun seperti upacara manyanggar dan mambuang pasilib. Penolakan Arsyad al-Banjari terhadap model keislaman mistik yang berkembang pada saat itu dan ritual-ritual lokal sesungguhnya didasarkan pada aspek 'amalî (praktis), tidak pada aspek naz̧harî (teoritis). Dalam kasus yang pertama, aliran wujudiyah, penolakan terjadi lebih dikarenakan sebagian aliran ini dalam praktiknya membenarkan untuk meninggalkan syariah seperti shalat bagi mereka yang telah mencapai maqam tertentu. Begitu juga untuk kasus yang terakhir, upacara manyanggar dan mambuang pasilih, Arsyad al-Banjari menolak legalitas ritual-ritual semacam ini lebih dikarenakan dalam praktiknya mengandung unsur-unsur yang bertentangan dengan Syariah. Arsyad al-Banjari tidak secara tegas mengatakan bahwa dua upacara ini mengandung syirik. Syirik hanya terwujud apabila ada keyakinan bahwa ritual-ritual tersebut dalam dirinya sendiri memiliki kemampuan menyembuhkan atau menghindarkan bencana. Selama tidak memiliki keyakinan sebagaimana disebutkan, menurut Arsyad al-Banjari, maka tidak ada syirik.

Uraian di atas menunjukkan bahwa risalah Tuhfat al-Râghibîn memandang Syariah dan Aqidah sebagai satu kesatuan.

\section{Iman dan Islam: Integrasi Aqidah dan Syariah}

Aqidah dan Syariah bagi Arsyad al-Banjari tidak dapat dipisahkan. Aqidah adalah ruh dari Syariah, dan Syariah merupakan implementasi dari Aqidah. Dalam Tuhfat al-Râghibîn integrasi Aqidah dan Syariah ini diartikulasikan dengan hubungan antara "iman" dan "Islam".

Berpegang kepada pandangan Asy'ariyah dan Maturidiyah, dua aliran yang dianggap merepresentasikan Ahl al-Sunnah wa al-Jamấah, bagi Datu Kalampayan hakikat iman adalah tashdîq atau meyakini dengan hati kebenaran apa yang dibawa Nabi Muhammad SAW. Ikrar dengan lisan, yakni mengucapkan dua kalimat syahadat, tidak termasuk dalam hakikat iman. Pandangan ini, sebagaimana diungkapkan juga oleh Arsyad al-Banjari, berbeda dengan pendapat sebagian kecil madzhab Hanafi dan aliran 
Asy'ariyah yang menganggap bahwa penuturan dengan lisan menjadi bagian integral dari keimanan. Artinya, untuk dikategorikan sebagai mukmin, seseorang tidak cukup hanya meyakini dengan hati, tapi juga harus mengikrarkannya dengan lisan. Dengan demikian, seseorang yang meyakini dengan hati kebenaran ajaran Nabi, tapi tidak menuturkannya dengan lisan dengan mengucap dua kalimat syahadat sementara ia masih mampu menuturkannya maka orang tersebut tidak dikategorikan sebagai mukmin baik secara lahir ataupun batin.

Menurut Arsyad al-Banjari, ikrar dengan lisan tidak menjadi bagian dari hakikat iman, melainkan hanya sebagai syarat untuk pemberlakuan syariat Islam. Oleh karenanya, kepada mereka yang mengucap dua kalimat syahadat diberlakukan ketentuan-ketentuan hukum Islam seperti sah dijadikan imam shalat, halal sembelihannya, dishalatkan apabila meninggal dunia, dikuburkan di pekuburan Muslim dan berlaku hukum waris baginya. Dalam konteks ini, orang yang meyakini dengan hati kebenaran ajaran Nabi Muhammad SAW dan menuturkan dua kalimat syahadat disebut Arsyad al-Banjari sebagai orang yang beriman secara lahir dan batin. Orang yang meyakini dengan hati kebenaran apa yang dibawa Nabi Muhammad SAW tapi tidak mengikrarkannya dengan lisan dikategorikan sebagai mukmin secara batin, namun secara lahir ia tidak disebut mukmin dan tidak berlaku ketentuan-ketentuan syariat Islam yang disebutkan tadi. Akan tetapi, menurut Arsyad al-Banjari selanjutnya, ia di akhirat masih termasuk penghuni surga dan terlepas dari kekal di dalam neraka karena masih termasuk kategori mukmin.

Demikian juga amal shaleh, bagi Arsyad al-Banjari ia tidak termasuk dalam hakikat iman. Beliau menolak pandangan Mu'tazilah yang meletakkan amal shaleh sebagai syarat mutlak bagi keimanan. Seseorang yang meyakini dengan hati kebenaran ajaran Islam dan mengikrarkannya dengan lisan dengan menuturkan dua kalimat syahadat, tapi tidak melaksanakan amal shaleh bagi Mu'tazilah tidak dapat di dikategorikan sebagai mukmin, namun demikian tidak juga dapat dikatakan sebagai kafir. Tepatnya, ia berada pada posisi antara mukmin dan kafir (al-manzilah baina almanzilatain). ${ }^{24}$ Konsep iman menurut Mu'tazilah tersebut sekilas tampak sama dengan makna iman yang didefinisikan sebagian besar kalangan fuqabâ', yakni bahwa iman adalah pembenaran dengan hati (tashdîq bi al-qalb), pengakuan dengan lisan (iqrâr bi allisân), dan amal dengan anggota tubuh ('amal bi al-arkân). Namun Arsyad al-Banjari mengungkapkan perbedaan mendasar antara keduanya. Bagi mayoritas ahli fiqih, amal shaleh tidak menjadi bagian integral dari keimanan, tetapi hanya menjadi syarat kesempurnaan iman. Dengan kata lain, letaknya di luar hakikat iman. Sedang menurut Mu'tazilah, amal shaleh termasuk dalam hakikat iman, artinya ia merupakan bagian yang tak terpisahkan dari keimanan. Mengikuti pandangan mayoritas ahli fiqih, Arsyad al-Banjari berpandangan bahwa amal shaleh tidak menentukan keimanan seseorang baik secara lahir ataupun batin. Amal shaleh hanyalah syarat untuk kesempurnaan iman, dan tidak menjadi bagian dari hakikat iman itu sendiri.

${ }^{24}$ Lihat Harun Nasution, Teologi Islam (Jakarta: UI-Press, 1986), 43; Harun Nasution, Islam Ditinjau dari Berbagai Aspeknya, Jilid 2 (Jakarta: UI-Press, 2002), 33. 


\section{Nuansa Fiqih dalam Pemikiran Teologi \\ Syekh Muhammad Arsyad Al-banjari pada Risalab Tubfat Al-râghibîn}

Namun perlu dicatat bahwa iman menurut Arsyad al-Banjari berkaitan erat dengan Islam, yakni ketundukan dan kepatuhan dalam menerima segala hukum-hukum Allah, baik itu diamalkan ataupun tidak. Tidak ber-Islam seseorang kalau tidak beriman dan tidak dianggap ber-iman seseorang kalau tidak ber-Islam. Islam tidak akan ada tanpa iman, begitu juga iman tidak sempurna tanpa Islam.

Dari sini dapat dipahami bahwa keimanan menurut Arsyad al-Banjari pada dasarnya merupakan konjungsi antara keyakinan akan kebenaran kenabian Nabi Muhammad SAW dan keyakinan kebenaran ajaran yang dibawanya. Secara logika, ini artinya seseorang dikatakan beriman jika dan hanya jika "meyakini kebenaran Nabi" dan "meyakini kebenaran ajaran yang dibawanya (Syariah)". Oleh karenanya, tidak dikatakan sempurna iman seseorang yang meskipun meyakini bahwa Muhammad SAW sebagai Nabi Allah tapi tidak meyakini pelaksanaan shalat lima waktu, misalnya, sebagai Syariah yang dibawa Nabi Muhammad SAW.

Definisi iman seperti ini, di satu sisi, bersifat moderat karena membatasi hakikat iman hanya pada keyakinan hati sehingga tanpa ikrar lisan dan amal shaleh seseorang masih disebut mukmin, tapi di sisi lain, bersifat ketat karena pengingkaran terhadap satu elemen Syariah saja, misalnya pelaksanaan shalat, dapat berimplikasi kepada kerusakan iman yang membawa kepada kekafiran. Sekali lagi ini menunjukkan bahwa Arsyad al-Banjari sangat menekankan aspek 'amalî dalam konsep aqidahnya.

\section{Modalitas Deontik Fiqih}

Sebelum membahas penggunaan modalitas deontik fiqih untuk menjelaskan persoalan-persoalan teologis dalam risalah Tuhfat al-Râghibin perlu terlebih dahulu diuraikan perbedaan antara fiqih dan Syariah. Syariah adalah jalan yang mesti ditempuh seorang Muslim sebagai pedoman hidup dalam berhubungan dengan Allah dan berinteraksi dengan sesama makhluk. Syariah murni bersumber dari wahyu, baik itu alQur'an atau al-Sunnah. Sementara fiqih adalah interpretasi atau pemahaman manusia terhadap syariah itu sendiri. ${ }^{25}$ Jadi, syariah bersifat ilahiyah, ahistoris, dan tidak bisa berubah. Sedangkan fiqih, sebagai hasil olah pikir manusia, tidak bersifat ilahiyah dan bisa berubah. Yang dimaksud dengan fiqih di sini adalah fiqih dalam konteks yang luas, termasuk juga di dalamnya ilmu ushul fiqih. Sebagai contoh, seorang muslim menurut ketentuan Syariah diperintahkan untuk melaksanakan shalat. Fiqih kemudian memberikan definisi dan batasan tentang shalat. Fiqih juga menentukan kategori hukum shalat, apakah itu wajib atau sunnah (mandûb).

Fokus pembahasan fiqih adalah hukum, baik itu yang disebut sebagai hukum takliffi, yakni hukum yang berkaitan dengan nilai tuntutan sebuah perbuatan bagi mukallaf, - mereka yang menjadi subyek dari tuntutan tersebut; atau hukum wadb ‘̂, yakni yang berkaitan dengan syarat atau kondisi-kondisi yang dapat menentukan nilai perbuatan yang disebutkan tadi. 26 Dalam bagian ini kita akan fokus kepada hukum taklifi yang

${ }^{25}$ Tentang perbedaan Syariah dan fiqih, lihat misalnya Jhon L. Esposito \& Natana J. DelongBas, Shariah: What Everyone needs to Know (New York: Oxford University Press, 2018), 34.

${ }^{26}$ Lebih detail tentang hukum lihat Abû Hâmid al-Ghazâlî, Al-Mustashfầ min Tlm al-Ushûll. (Bûlâq: al-Mathba’at al-Amị̣̂̂yyah, 1324H/1906), 55-99. 
berkonsentrasi pada modalitas deontik (deontik modality), yakni keharusan (obligation) atau kebolehan (permission) suatu perbuatan. Mayoritas ulama mengungkapkan ada lima

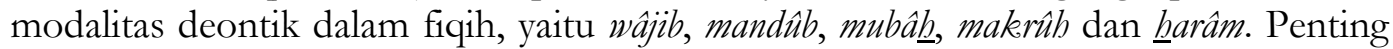
untuk dicatat bahwa lima modalitas deontik tersebut mengambil bentuk imperatif heteronom (beteronomous imperatives) karena nilai tuntutan sebuah perbuatan ditentukan oleh akibat dari perbuatan tersebut. ${ }^{27}$ Dalam hal ini nilainya diklasifikasi berdasarkan kualifikasi pahala dan dosa yang diakibatkan oleh perbuatan tersebut. Dalam konteks ini mayoritas ahli hukum Islam umumnya mendefinisikan lima modalitas deontik ini sebagai berikut ${ }^{28}$ :

1) Wajib artinya diberi pahala ketika dilakukan dan berdosa apabila ditinggalkan.

2) Mandûb artinya diganjar pahala ketika dilakukan; dan tidak berpahala juga tidak berdosa jika ditinggalkan.

3) Mubâh artinya tidak berpahala dan tidak berdosa ketika dilakukan atau ditinggalkan.

4) Makrûh artinya berpahala jika ditinggalkan; dan tidak berpahala juga tidak berdosa jika dilakukan.

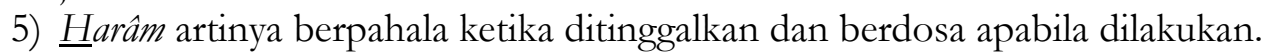

Salah satu isu yang dibahas dalam risalah Tubfat al-Râghibin adalah masalah bid'ah, yakni inovasi yang berkaitan dengan perbuatan atau keyakinan yang tidak ada dasarnya dalam al-Qur'an ataupun al-Sunnah. Dalam konteks ini, mengikuti pandangan dalam madzhab Syafi'i, bid'ah diklasifikasi sesuai dengan lima modalitas deontik dalam fiqih: Bid'ah Wajib, Bid'ah Sunnah Bid'ah Mubah, Bid'ah Makruh dan Bid'ah Haram. Arsyad al-Banjari bependapat bahwa keyakinan dalam aliran Jabariyah, Qadariyah, Murjiah, Mujasamah, Wujudiyah (yakni Wujudiyah Mulhid), serta semua keyakinan yang serupa dengan paham-paham tersebut termasuk dalam kategori Bid'ah Haram yang dapat membawa kepada kekufuran. ${ }^{29}$ Disini terlihat bahwa modalitas deontik fiqih berpengaruh dalam pandangan teologi Arsyad al-Banjari.

Lebih jauh, sebagaimana diungkapkan sebelumnya, bagi Arsyad al-Banjari, menerima atau membenarkan ketentuan Syariah Islam merupakan syarat bagi kesempurnaan iman. Oleh karena itu, segala keyakinan atau perbuatan yang bertolak belakang dengan Syariah tidak dapat diterima. Dalam observasinya, Arsyad al-Banjari menggunakan modalitas deontik fiqih untuk melihat hal ini. Misalnya beliau memasukkan dalam kategori kafir orang yang menganggap boleh (mubâh ) sesuatu yang

${ }^{27}$ Lihat Shahid Rahman, J. G. Granström, A. Farjami, "Legal Reasoning and Some Logic After All. The Lessons of the Elders". Dalam D. Gabbay, L. Magnani, W. Park, \& A.-V. Pietarinen, Natural Arguments. A Tribute to John Woods (London: CollegePublications, 2019), 743-780; Shahid Rahman, Farid

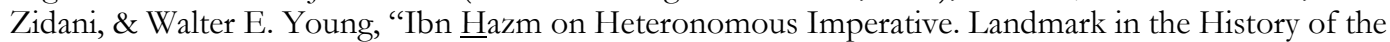
Logical Analysis of Legal Norms". Dalam P. McNamara, A. Jones, \& M. Brown, Deontic Logic. (Synthese Library-Springer.Rahman, 2020).

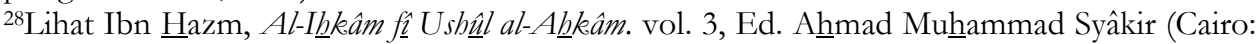

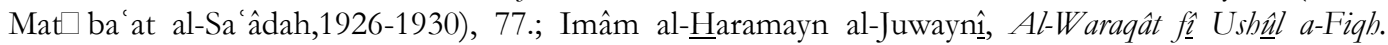
Dalam Catatan Pinggir pada al-Mahallị̂s Syarh al-Waraqât. (Hyderabad: Markaz Tau'iyyat al-Fiqh alIslâmî, 1955) p. 4.

${ }^{29}$ Arsyad al-Banjari, Tuhfat al-Râghibîn, Ed. Mahmud Siddiq (Teluk Selong, Martapura, 1983), 35. 


\section{Nuansa Fiqih dalam Pemikiran Teologi \\ Syekh Muhammad Arsyad Al-banjari pada Risalah Tuhfat Al-râghibîn}

disepakati sebagai harâm seperti zina, homoseksual, minuman keras dan mencuri. Ini juga berlaku bagi orang yang menolak kewajiban shalat lima waktu dan puasa bulan Ramadhan. ${ }^{30}$ Perlu diingat kembali bahwa modalitas deontik seperti wâjib dan harâm diproduksi dalam ilmu fiqih.

Selain itu, historisitas modalitas deontik sebuah perbuatan dalam hal terjadi penolakan atas perbuatan tersebut, menurut Arsyad al-Banjari, mempengaruhi tingkat keimanan seseorang. Beliau mengungkapkan misalnya bahwa orang yang beranganangan agar Allah tidak mengharamkan zina, membunuh dan menganiaya orang dikategorikan sebagai kafir karena perbuatan-perbuatan tersebut telah diharamkan semenjak Islam diturunkan. Sementara orang yang berangan-angan agar Allah tidak mengharamkan minuman keras dan mengawini saudara kandung tidak dapat dikategorikan sebagai kafir karena minuman keras diperbolehkan pada masa-masa awal Islam dan mengawini saudara kandung diperbolehkan menurut syariat Nabi Adam AS. ${ }^{31}$ Sekali lagi, ini menunjukkan bahwa modalitas deontik fiqih yang melihat aspek praktis ('amali) sebuah perbuatan berpengaruh dalam pandangan teologi Arsyad alBanjari.

\section{Model Penalaran dan Argumentasi Fiqih}

Dalam fiqih dikenal adanya hirarki dalil (evidence) yang menentukan suatu hukum apakah ia bersifat definitif (qath'i) atau spekulatif (zhannì). Dalil hukum yang diambil langsung dari teks (nashsh) al-Qur'an atau hadits mutawatir oleh ahli hukum Islam disebut bersifat definitif dan secara epistemis sangat kuat. Berbeda dengan dalil yang diambil, misalnya, dari qiyâs atau hadits ahad. Tampaknya model hirarki penalaran fiqih ini juga berpengaruh terhadap pemikiran teologi Arsyad al-Banjari pada risalah Tuhfat al-Râghibîn, terutama dalam melihat tingkat kekufuran yang diakibatkan oleh suatu bid'ah. Menurut beliau, bid'ah yang bertentangan dengan nashsh al-Qur'an atau hadits yang disepakati keshahihannya membawa kepada kekafiran. Sementara bid'ah yang bertentangan dengan qiyâs atau hadits yang keshahihannya masih diperselisihkan tidak membawa kepada kekafiran, tapi masih termasuk bid'ah sayyi'ah yang wajib bagi pelakunya untuk bertaubat. ${ }^{32}$

Salah satu contoh bid'ah sayyi'ah yang dibahas panjang dalam risalah Tuhfat alRâghibîn adalah dua ritual lokal, manyanggar dan mambuang pasilih. Untuk menolak upacara-upacara lokal ini Arsyad al-Banjari mengungkapkan argumennya dalam kerangka dialogis dengan format tanya-jawab (su'âl-jawâb) yang memasukkan model penalaran analogi (qiyâs) dan teori argumentasi (jadal) dalam fiqih. ${ }^{33}$ Penolakan terhadap upacara manyanggar dan mambuang pasilib dimulai dengan mengungkapkan tiga macam kemungkaran yang terkandung dalam kegiatan-kegiatan tersebut. Secara berurutan, tiga

${ }^{30}$ Ibid, 11

${ }^{31}$ Ibid, 16

${ }^{32}$ Ibid, 36

${ }^{33}$ Model argumen dialektis Arsyad al-Banjari untuk menolak upacara manyanggar dan mambuang pasilih dapat dilihat di Iqbal dan Rahman (2021), "Arsyad Al-Banjari's Dialectical Model for Integrating Indonesian Traditional Uses into Islamic Law", Argumentation, 35, 2021, 73-99. 
kemungkaran yang dimaksud adalah: 1) tabdzîr, yakni menghambur-hamburkan harta di jalan yang tidak benar; 2) mengikuti kehendak dan tipuan syaitan; 3) syirik atau menyekutukan Allah. ${ }^{34}$ Menariknya, meskipun dalam urutannya syirik diletakkan dalam posisi terakhir, namun argumen dialogis yang disajikan dimulai dengan isu ini.

Menurut Arsyad al-Banjari upacara manyanggar dan mambuang pasilih memiliki kemiripan dengan praktek syirik dalam hal adanya keyakinan bahwa upacara-upacara tersebut (yakni sesuatu selain Allah) dapat menyembuhkan penyakit dan menghindarkan dari bencana. ${ }^{35}$ Model penalaran seperti ini dalam ilmu fiqih disebut dengan qiyâs al-shabah. Dalam model qiyâs ini ashl atau kasus-asal (praktik syirik) dan far atau kasus-cabang (upacara manyanggar dan mambuang pasilib) disamakan karena memiliki sifat yang sama (meyakini ada sebab lain selain Allah), dan dalam konteks ini sifat tersebut tidak menjadi sebab atau 'illat bagi hukum. Apabila ia menjadi 'illat bagi hukum maka qiyâs tersebut disebut sebagai qiyâs al-íllah. ${ }^{36}$ Dalam konteks ini, tampaknya Arsyad al-Banjari memang tidak ingin mengungkapkan secara tegas bahwa upacara-upacara lokal Banjar tersebut sebagai syirik. Ia menjadi syirik apabila diyakini bahwa upacara-upacara tersebut memiliki kemampuan dalam dirinya sendiri untuk menyembuhkan penyakit atau menghindarkan bencana karena itu bertentangan dengan taubî́ al-af'al, dan orang yang memiliki keyakinan seperti itu menjadi kafir. Jika diyakini bahwa kemampuan tersebut pada dasarnya tidak dimiliki oleh upacara-upacara tersebut dalam dirinya sendiri, tapi merupakan pemberian Allah, atau, lebih tepatnya, Allah semacam mendelegasikan kemampuan tersebut kepada upacara-upacara tersebut, maka menurut Arsyad al-Banjari mereka yang memiliki keyakinan seperti itu hanya termasuk dalam ahli bid'ah dan fasik. ${ }^{37}$

Dalam dialog yang disajikan oleh Arsyad al-Banjari dalam risalah Tubfat alRâghibin tampaknya para pendukung upacara manyanggar dan mambuang pasilib memiliki keyakinan yang berbeda dengan keyakinan sebagaimana disebutkan di atas. Menurut keyakinan mereka, yang menyembuhkan dan menghindarkan dari bencana pada hakikatnya adalah Allah, tapi dijadikan kebiasaan ('adah) apabila dilaksanakan upacara manyanggar dan mambuang pasilih maka disembuhkanlah penyakit dan dihindarkan dari bencana. Sama seperti bahwa yang membakar dan menghilangkan lapar sebenarnya adalah Allah, tapi dijadikan kebiasaan bahwa apabila disentuhkan api pada sesuatu yang kering maka ia terbakar dan apabila makanan dimakan maka hilanglah lapar. ${ }^{38}$ Dalam hal ini, para pendukung upacara lokal juga menggunakan qijâs sebagaimana yang digunakan oleh Arsyad al-Banjari untuk menyamakan manyanggar dan mambuang pasilih dengan praktik syirik.

Namun qiyâs tersebut ditolak oleh Arsyad al-Banjari dengan menggunakan salah satu model bantahan dalam teori jadal fiqih, farq (pembedaan), yakni dengan

${ }^{34}$ Arsyad al-Banjari, Tubfat al-Râghibîn, 36-39.

${ }^{35}$ Ibid, 38

${ }^{36}$ Lihat Abûu Ishâq al-Shịrâzị̂, Al-Luma' fî̀ Ushbûl al-Fiqh. Ed. Muh $\square$ yî al-Dîn Dîb Mustû and Yûsuf 'Alî Badîwî̀, (Damascus; Beirut: Dâr al-Kalam al-T $\square$ ayyib; Dâr Ibn Kathị̂, 1995), 204-209.

${ }^{37}$ Arsyad al-Banjari, Tuhfat al-Râghibîn, 39.

${ }^{38}$ Ibid 


\section{Nuansa Fiqih dalam Pemikiran Teologi \\ Syekh Muhammad Arsyad Al-banjari pada Risalah Tuhfat Al-râghibîn}

memperlihatkan perbedaan spesifik antara dua hal yang dianalogikan. ${ }^{39}$ Dengan farq, api dan makanan dibedakan dengan upacara manyanggar dan mambuang pasilib. Api memang kebiasaannya secara alamiah membakar, demikian juga makanan memang kebiasaannya secara alamiah mengenyangkan. Sementara manyanggar dan mambuang pasilib tidak kebiasaannya secara alamiah menyembuhkan atau menghindarkan bencana sehingga meskipun setelah melaksanakan upacara-upacara tersebut terjadi kesembuhan menurut Arsyad al-Banjari itu hanyalah sebuah kebetulan. ${ }^{40}$

Pendukung upacara manyanggar dan mambuang pasilib juga menolak pendapat yang menyatakan bahwa kedua upacara tersebut mengandung tabdzî dengan menyatakan bahwa dalam upacara-upacara tersebut sesungguhnya mereka memberikan makan keluarga mereka yang gaib dan masih hidup hingga sekarang; dan ini dapat diqiyaskan dengan memberi makan keluarga atau sahabat yang ada (tidak ghaib). ${ }^{41}$ Qiyâs ini ditolak Arsyad al-Banjari dengan menyangkal (man $)$ akan keberadaan keluarga yang ghaib tersebut. Rujukan para pendukung manyanggar dan mambuang pasilih ke cerita-cerita orang tua yang turun temurun dan kesaksian orang kesurupan untuk membuktikan itu tidak dapat diterima secara syariah. Bahkan, merujuk kepada sebuah hadits, Arsyad al-Banjari menunjukkan bahwa mengikuti ucapan orang yang kesurupan tersebut sesungguhnya menuruti permintaan syaitan. ${ }^{42}$

Meskipun menerima bahwa mereka mengikuti permintaan syaitan, namun, secara mengejutkan, pendukung upacara manyanggar dan mambuang pasilib mengklaim bahwa praktik tersebut tidak terlarang. Dalam hal ini menurut mereka pemberian sesajen kepada syaitan dapat diniatkan memberi makanan anjing dengan tujuan untuk

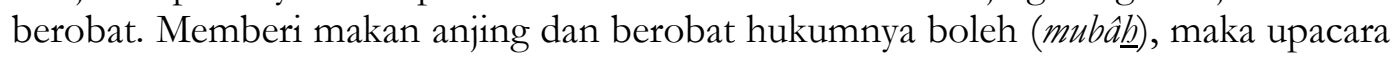
manyanggar dan mambuang pasilih juga boleh. Arsyad al-Banjari menolak argumen ini dengan memberikan contoh tandingan: membunuh seorang manusia dengan niat membunuh tikus dengan maksud untuk mengobati sakit liver tidak menjadikan pembunuhan itu boleh; demikian juga, melakukan zina dengan seorang wanita dengan niat melakukan hubungan seksual dengan istri sendiri dengan maksud mengobati rematik tidak menjadikan perbuatan zina tersebut menjadi boleh. ${ }^{43}$ Dalam teori jadal fiqih, model penolakan seperti ini disebut sebagai naqdb. ${ }^{44}$ Dengan itu Arsyad al-Banjari menunjukkan bahwa melakukan sebuah perbuatan terlarang yang diniatkan dengan sesuatu yang boleh dengan maksud untuk kesembuhan tidak menjadikan perbuatan terlarang itu menjadi boleh. Oleh karena itu, memberi makan syaitan dengan niat memberi makan anjing dengan maksud kesembuhan tidak menjadikan perbuatan memberi makan syaitan tersebut menjadi boleh.

${ }^{39} A b \underline{u}$ Ishâq al-Shịrâzị̂, Al-Ma' ûnah fî al-Jadal. Ed. 'Alî̀ b. 'Abd al-'Azị̂z al-'Umayrînî. (AlShafâh, Kuwait: Manshụ̂rât Markaz al-Makhthụ̂thât wa-al-Turâts, 1987), 116-117

${ }^{40}$ Arsyad al-Banjari, Tuhfat al-Râghibîn, 39-40

${ }^{41}$ Ibid, 40.

${ }^{42}$ Ibid, 41.

${ }^{43} \mathrm{Ibid}, 42$

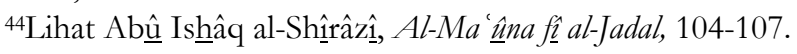

Khazanah, Vol. 19 (1), 2021 
Arsyad al-Banjari juga menggunakan model bantahan farq untuk menunjukkan perbedaan antara memberi makan anjing dengan memberi sesajen (kepada syaitan) dalam upacara manyanggar dan mambuang pasilih. Makanan yang diberikan kepada anjing adalah makanan sisa, sementara makanan yang diberikan dalam upacara-upacara tersebut adalah makanan yang baik dan dihiasi dengan indah. Ini menunjukkan bahwa terhadap anjing tidak ada penghormatan, sementara terhadap syaitan ada penghormatan. Selain itu, menurut Arsyad al-Banjari, upacara manyanggar dan mambuang pasilih tidak dapat disebut sebagai obat baik secara adat ataupun syariah karena obat biasanya ditelan, disemprotkan atau dioleskan pada tubuh. ${ }^{45}$

Dari uraian di atas tampak bahwa pandangan Arsyad al-Banjari tentang kebid'ah-an upacara manyanggar dan mambuang pasilib didasarkan pada argument dialektis yang bersandar pada model penalaran analogi (qiyâs) dan teori argumentasi (jadal) dalam fiqih.

\section{Struktur Dalam (Deep Structure) Hukum Wadh'î}

Dalam kajian filsafat (strukturalisme), struktur dibedakan menjadi dua: struktur permukaan (surface structure) dan struktur dalam (deep structure). Struktur permukaan adalah relasi antar elemen pada permukaan, sedang struktur dalam adalah sistem tertentu yang dibangun berdasarkan struktur permukaan. ${ }^{46}$ Pada permukaannya sebuah struktur bersifat dinamis. Ia tidak statis karena ada semacam prinsip transformasi dengan tanpa keluar dari batas-batas sistem yang di dalam. ${ }^{47}$ Misalnya lagu "Kangen" yang dulu dinyanyikan oleh grup Dewa 19 memiliki aransemen yang berbeda ketika dinyanyikan kembali oleh Chrisye. Namun perbedaan aransemen antar keduanya tidak merubah lagu tersebut. Aransemen baru yang dibuat pun tidak akan dapat keluar dari sistem lagu itu.

Dalam risalah Tuhfat al-Râghibîn, tampak ada struktur dalam (deep structure) hukum wadh ‘̂,. Sebagaimana diungkapkan sebelumnya, hukum wadh $\hat{\imath}$ berkaitan dengan syarat atau kondisi-kondisi yang dapat menentukan nilai suatu ibadah atau mu'amalah.

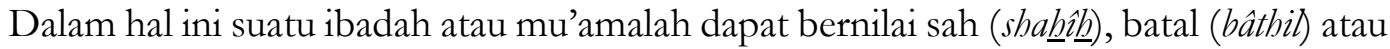
rusak (fâsid). Sebuah akad, misalnya, sah apabila semua rukun dan syarat terpenuhi, sebaliknya jika tidak terpenuhi maka ia batal. Apabila semua rukun dan syarat terpenuhi tapi ada sesuatu yang dianggap mengurangi kesempurnaan akad maka is rusak (fâsid). Ambil contoh akad nikah, jika syarat dua orang saksi tidak terpenuhi maka akad nikah tersebut batal. Demikian juga akad nikah batal apabila wanita yang dinikahi ternyata masih pada masa 'iddah. Sebagian ulama berpendapat bahwa akad nikah fâsid apabila dilakukan tanpa persetujuan mempelai wanita. Perbedaan antara keduanya, apabila akad nikah batal, maka implikasi dari akad nikah tersebut tidak diperoleh. Jika ingin melanjutkan, maka harus mengulang akad nikah dengan menyempurnakan rukun dan syaratnya. Sementara apabila akad nikah rusak, implikasi dari akad nikah hanya ditunda.

${ }^{45}$ Arsyad al-Banjari, Tuhfat al-Râghibîn, 42-43.

${ }^{46}$ Heddy Shri Ahimsa-Putra, Strukturalisme Levi-Strauss: Mitos dan Karya Sastra, (Yogyakarta: Galang Press, 2001), 61-62.

47Jean Piaget, Strukturalisme, terj. Hermoyo, (Jakarta: Yayasan Obor Indonesia, 1995), 7-9. 


\section{Nuansa Fiqih dalam Pemikiran Teologi \\ Syekh Muhammad Arsyad Al-banjari pada Risalah Tubfat Al-râghibîn}

Jika, dalam kasus akad nikah tanpa izin mempelai wanita, ternyata si mempelai wanita rela atau setuju, maka sempurnalah akad nikah tersebut dan tidak harus diulang. Begitu juga dengan ibadah haji, jika seseorang murtad pada saat melaksanakan ibadah haji, maka hajinya batal. Tapi apabila ia melakukan hubungan suami isteri saat ibadah haji maka hajinya rusak. Haji yang batal tidak bisa diulang atau disempurnakan. Sementara haji yang rusak, masih bisa diulang dan disempurnakan dengan memenuhi beberapa kondisi tertentu. ${ }^{48}$

Dilihat dari sistematika risalah Tuhfat al-Râghibîn tampaknya konsep keimanan dalam risalah ini mengikuti struktur dalam (deep structure) dari sistem hukum wadh $\hat{\imath}$ di atas. Menggunakan tiga kategori nilai dalam hukum wadh $\hat{\imath}$, secara implisit Arsyad alBanjari mengklasifikasi nilai keimanan menjadi tiga: sah, batal atau rusak. Keimanan dikatakan sah apabila terpenuhi apa yang disebut sebagai hakikat iman dan Islam. Hakikat iman adalah meyakini dalam diri bahwa Allah adalah Tuhan semesta alam dan Muhammad adalah Nabi-Nya. Sedang hakikat Islam adalah meyakini kebenaran ajaran yang dibawa Nabi Muhammad SAW. Hakikat iman, kalau kita analogikan dengan haji, adalah rukun yang kalau tidak dilaksanakan ibadah haji menjadi batal. Sementara bakikat Islam adalah wajib haji yang apabila ditinggalkan haji tetap sah, tapi harus melaksanakan sanksi yang ditetapkan. Misalnya, seorang Jemaah haji yang tidak melontar jumrah diharuskan membayar dam atau fidyah.

Perkataan atau perbuatan yang bertentangan hakikat iman, menurut Arsyad alBanjari, menjadikan iman seseorang batal, seperti murtad. Iman yang batal, misal dikarenakan murtad tadi, tidak dapat diperbaiki kecuali dengan bersyahadat kembali. ${ }^{49}$ Selama tidak bersyahadat, maka orang tersebut berada dalam kekafiran. Sementara apabila seseorang mengatakan atau melakukan sesuatu yang mencederai bakikat Islam, maka keimanannya rusak atau fâsid. Orang yang melaksanakan upacara manyanggar dan mambuang pasilih, misalnya, termasuk orang yang rusak imannya karena ritual-ritual tersebut bertentang dengan ajaran Islam. Meski begitu, imannya tidak batal, dan tidak diwajibkan atasnya untuk bersyahadat kembali, hanya diwajibkan atasnya untuk bertaubat.

\section{Simpulan}

Dari uraian di atas tampak bahwa nuansa fiqih sangat kental dalam Tuhfat alRâghibîn. Nuansa fiqih itu tampak dari penggunaan modalitas deontik, model penalaran dan argumentasi dan struktur dalam hukum wadh $\grave{\imath}$ dalam fiqih untuk menjelaskan peroalan-persoalan teologis. Nuansa fiqih juga terlihat dari kecenderungannya kepada aspek praktis ('amali) sehingga tidak banyak aspek teoritis (ną̧har) yang dibicarakan dalam risalah ini. Kita tidak menemukan dalam risalah ini argumen yang menjadi dasar untuk keberadaan sifat-sifat Allah. Kita juga tidak menemukan bagaimana perdebatan teoritis tentang apakah pelaku dosa besar itu beriman atau kafir. Tampaknya risalah ini

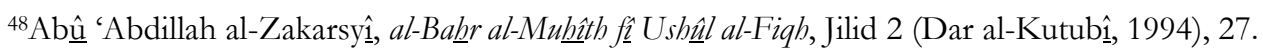

${ }^{49}$ Arsyad al-Banjari, Tubfat al-Râghibîn, 48. 
memang disusun untuk memberikan petunjuk praktis tentang aqidah yang benar, dalam hal ini adalah aqidah Ahl al-Sunnah wa al-Jamâ'ah sebagaimana keyakinan Arsyad al-Banjari.

Meski begitu, bukan berarti dalam penjelasannya risalah ini bersifat murni dogmatis. Dengan menggunakan pendekatan fiqih, penjelasan-penjelasan berkaitan dengan aspek-aspek praktis dalam risalah ini dijelaskan secara logis dan argumentatif. Mari kita ingat kembali bagaimana Arsyad al-Banjari membedakan keimanan orang yang mengangankan dibolehkannya zina dengan keimanan orang yang mengangankan dibolehkannya minuman keras. Yang pertama menjadi kafir apabila tidak bertobat karena zina telah dilarang semenjak turunnya Islam, sedangkan yang kedua tidak menjadi kafir karena minuman keras dibolehkan pada masa-masa awal Islam.

Argumentasi yang lebih canggih digunakan untuk menolak upacara manyanggar dan mambuang pasilih. Dalam hal ini Arsyad al-Banjari menggunakan qiyâs fiqih atau analogi yang diformat secara dialektis (jadali).

Pelajaran yang dapat dipetik dari sini adalah bahwa Islamisasi harus dibangun melalui pemahaman yang argumentatif dan dialektis. Oleh karenanya ruang dialog bagi mereka yang berbeda pendapat harus terbuka karena pengetahuan pada dasarnya hanya dapat dicapai dengan usaha kolektif. Ini menarik kalau kita bandingkan dengan pola Islamisasi yang berkembang belakangan ini, terutama yang tergambar dalam media sosial. Dalam media sosial, ruang yang terbuka seringkali tidak menghasilkan dialog yang argumentatif.

Di sisi lain, nuansa fiqih dalam Tubfat al-Râghibîn semakin memperkuat bahwa risalah ini adalah karangan Arsyad al-Banjari karena beliau memiliki latar belakang sebagai seorang ahli fiqih dengan bukti beberapa karyanya di bidang fiqih seperti Sabîl al-Mubtadîn, Kitâb al-Nikâh, Luqthat al-'Ajlân dan Kitâb al-Farâidh.

Kajian tentang teologi Arsyad al-Banjari dalam karya ini sebenarnya masih terbatas pada dialektika antara fiqih dan teologi dalam risalah Tubfat al-Râghibin. Oleh karena itu, ini belum menggambarkan secara utuh pemikiran Arsyad al-Banjari. Tentu dialektika antara fiqih, teologi dan tasawuf dalam pemikiran Arsyad al-Banjari menjadi kajian yang perlu dilakukan di masa mendatang.

\section{Daftar Pustaka}

'Âyish, 'Abd al-Fattâh dan Qaishar. Mu'jam al-Adibbâ' min 'Ashr al-Jâhili hattâ sana 2002. Vol. 4. Beirut: Dâr al-Kutub al-'Ilmiyya, 2003

Ahimsa-Putra, Heddy Shri. Strukturalisme Levi-Strauss: Mitos dan Karya Sastra. Yogyakarta: Galang Press, 2001.

Arsyad al-Banjari, Tubfat al-Râghibîn, Ed. Mahmud Siddiq. Teluk Selong, Martapura, 1983.

Azra, Azyumardi. The Origins of Islamic reformism in Southeast Asia: networks of MalayIndonesian and Middle Eastern 'Ulama' in the seventeenth and eighteenth centuries. Crows Nest; Honolulu: Allen \& Unwin; University of Hawai'i Press, 2004.

Bakker, Anton dan Achmad Charris Zubair. Metodologi Penelitian Filsafat. Yogyakarta: Penerbit Kanisius, 1990. 
Creswell, John W. Research Design: Qualitative, Quantitative, and Mixed Methods Approaches, Third Edition. Los Angeles: Sage, 2009.

El-Muhammady, Muhammad 'Uthman. "Aqidah Ahli Sunnah Wal-Jamaah menurut Syeikh Muhammad Arsyad al-Banjari”. Dalam Abdul Rahman Abdullah, Biografi Agung Sheikh Arshad al-Banjari. Shah Alam, Selangor: Karya Bestari, 2016.

Esposito, John L. \& Natana J. Delong-Bas, Shariab: What Everyone needs to Know. New York: Oxford University Press, 2018.

al-Ghazâlî, Abû Hâmid. Al-Mustashfâ min Tlm al-Ushûl. Bûlâq: al-Mathba'at alAmîrìyah, 1324H/1906.

Halidi,Yusuf. Ulama Besar Kalimantan Selatan Syekh Arsyad al-Banjari. Surabaya: alIkhsan, 1968.

Hasan, Norhaidi. "The Tuhfat al-Raghibin: The Work of Abdul Samad al-Palimbani or Muhammad Arsyad al-Banjari?” Bijdragen tot de Taal-, Land-en Volkenkunde (BKI) 163-1, 2007.

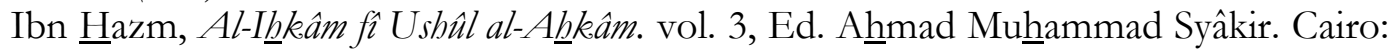
Mat $\square$ ba 'at al-Sa '̂adah,1926-1930

Iqbal, Muhammad dan Shahid Rahman "Arsyad Al-Banjari's Dialectical Model for Integrating Indonesian Traditional Uses into Islamic Law", Argumentation, Vol. 35, 2021.

al-Jabartî, 'Abd al-Rahman. Târîkh 'Ajâỉb al-Âtsâr fì al-Tarâjum wa al-Akhbâr, vol.1. Beirut: Dâr al-Jîl, 1998

al-Jâbî, Bassâm 'Abd al-Wahâb. "Tarjamah Muhammad ibn Sulaymân al-Kurdî/alKardî”. Dalam Muhammad b. al-Kurdî, al-Fawầid al-Madaniyyah. Libanon: Dâr Nûr al-Shabâh and al-Jaffân wa al-Jâbî, 2011.

Jahja, Zurkani. "Pemikiran Syeikh Muhammad Arsyad al-Banjari dalam Bidang Tauhid". Dalam Abdul Rahman Abdullah, Biografi Agung Sheikh Arshad alBanjari. Dalam Abdul Rahman Abdullah, Biografi Agung Sheikh Arshad al-Banjari. Shah Alam, Selangor: Karya Bestari, 2016.

al-Juwaynî, Imâm al-Haramayn. Al-W araqât fî Ushûl a-Fiqh. Dalam Catatan Pinggir pada al-Mahallî̀’s Syarh al-Waraqât. Hyderabad: Markaz Tau'iyyat al-Fiqh al-Islâmî, 1955.

Kahâhla, 'Umar Ridhâ. Mu'jam al-Mu'allifinn; Tarâjum Mu'alifí al-Kutub al-'Arabiyyah. Vol.2. Beirut: Mu'assasat al-Risâlah, 1993

Kartono, Kartini. Pengantar Metodologi Riset Sosial. Bandung : Mandar Maju, 1996.

Mujiburrahman, M. Rusydi, Muhammad Iqbal \& Adi Hatim, Pemikiran Teologi Syekh Mubammad Arsyad al-Banjari dalam Kitab Hidâyat al-Mustarsyidîn, UIN Antasari Banjarmasin, Banjarmasin, 2021.

Mujiburrahman. "Islamic Theological Texts and Contexts in Banjarese Society: An Overview of the Existing Studies". Southeast Asian Studies, 3/3, 2014.

Munadi, Fathullah. Teks dan Naskah Sabîl al-Mubtadin: Kajian Filologi atas Karya Syekh Mubammad Arsyad.

Retrieved from 
https://www.academia.edu/41958304/teks_dan_naskah_sab\%c4\%aal_al_m uhtad\%c4\%aan_kajian_filologi_atas_karya_syekh_muhammad_arsyad.

Nasution, Harun. Islam Ditinjau dari Berbagai Aspeknya, Jilid 2. Jakarta: UI-Press, 2002. Nasution, Harun. Teologi Islam. Jakarta: UI-Press, 1986.

Noor, Irfan. "Visi Spiritual Masyarakat Banjar", Al-Banjari, Vol. 12 No. 2 Juli 2013.

Noor, Muhammad Iqbal. "Nalar Keislaman Urang Banjar", Al-Banjari, Vol.10. No.2, 2011.

Perlmann, Moshe. "Shaykh al-Damanhûrî against the churches of Cairo (1739)". Actas IV Congresso de Estudos Arabes e Islamicos: Coimbra-Lisboa, 1 a 8 de 'setembro de 1968. Leiden: Brill, 1971).

Piaget, Jean. Strukturalisme, terj. Hermoyo. Jakarta: Yayasan Obor Indonesia, 1995.

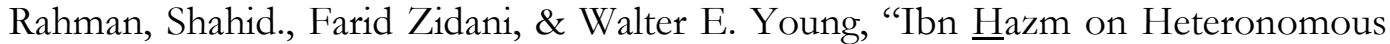
Imperative. Landmark in the History of the Logical Analysis of Legal Norms". Dalam P. McNamara, A. Jones, \& M. Brown, Deontik Logic. Synthese LibrarySpringer.Rahman, 2020.

Rahman, Shahid., J. G. Granström, A. Farjami, "Legal Reasoning and Some Logic After All. The Lessons of the Elders”. Dalam D. Gabbay, L. Magnani, W. Park, \& A.-V. Pietarinen, Natural Arguments. A Tribute to John Woods. London: CollegePublications, 2019.

Rusydi, M. "Analisis atas Tuhfah ar-Râghibîn Karya Muhammad Arsyad al-Banjari” AlBanjari, Vol. 9 No.1, 2010.

"Ideologi dan Epistemologi Kitab Tubfah ar-Râghibîn Karya Muhammad Arshad al-Banjari, Islamica: Jurnal Studi Keislaman, Vol. 8, No.2, 2014.

al-Shîrâzî, Abû Ishâq. Al-Luma' fî̀ Ushûl al-Fiqh. Ed. Muh $\square$ yî al-Dîn Dib Mustû and Yûsuf 'Alî Badîwî. Damascus; Beirut: Dâr al-Kalam al-T $\square$ ayyib; Dâr Ibn Kathîr, 1995. Al-Ma'ûna fî al-Jadal. Ed. 'Alî b. 'Abd al-'Azîz al-'Umayrînî. Al-Shafâh, Kuwait: Manshûrât Markaz al-Makhthûthât wa-al-Turâts, 1987.

Steenbrink, K. A. Beberapa Aspek tentang Islam di Indonesia Abad ke19. Jakarta: Bulan Bintang, 1984.

Syukur, Aswadie. "Pemikiran Syeikh Muhammad Arsyad al-Banjari dalam Bidang Fiqh (1); Kitab Sabil al-Muhtadin”. Dalam Abdul Rahman Abdullah, Biografi Agung Sheikh Arshad al-Banjari. Shah Alam, Selangor: Karya Bestari, 2016.

Naskah Risalah Tubfatur Raghibin. Laporan Penelitian IAIN Antasari Banjarmasin, 1990

van Bruinessen, M. "Kurdish 'Ulama and their Indonesian disciples" [revised version of: "The impact of Kurdish `ulama on Indonesian Islam"]". Les annales de l'autre Islam, 5, 1998.

Yusran, Study Tentang Risalab Tubfatur Raghibin, Skripsi, Fakultas Ushuluddin IAIN Antasari, Banjarmasin, 1988

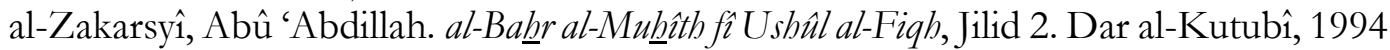
al-Zarkalî, Khair al-Dîn. al-A'lâm. vol.4. Beirut: Dâr al-'Ilm li al-Malâyîn, 2002. 